\author{
Sequencing Batch Reactor (SBR)에서 \\ 포기시간 변경에 따른 영향 (1) - 영양염류 제거 \\ 정노성 · 박영식 ${ }^{1} \cdot$ 김동석 \\ 대구가톨릭대학교 환경과학과, ${ }^{1)}$ 대구대학교 보건과학부 \\ (2010년 8월 24일 접수; 2010년 9월 11일 수정; 2010년 9월 25일 채택)
}

\title{
Effects of the Variation of Aeration Time in Sequencing Batch Reactor (SBR) (1) - Nutrient Removal
}

\author{
Nosung Jeong, Youngseek Park¹), Dongseog Kim ${ }^{*}$ \\ Department of Environmental Science, Catholic University of Daegu, Gyeongbuk 712-702, Korea \\ ${ }^{1)}$ Department of Health \& Environment, Daegu University, Gyeongbuk 712-830, Korea \\ (Manuscript received 24 August, 2010; revised 11 September, 2010; accepted 25 September, 2010)
}

\begin{abstract}
The effect of the variation of aeration time on the removal of organics, nitrogen and phosphorus using synthetic wastewater was investigated in sequencing batch reactors (SBRs) which included DNPAOs and DNGAOs. The cycling times in four SBRs were adjusted to 12 hours and then included different aerobic times as $1 \mathrm{hr}, 2.5 \mathrm{hr}, 4 \mathrm{hr}$ and $5.5 \mathrm{hr}$, respectively. Four SBR systems have been operated and investigated for over 40 days. Average TOC removal efficiencies were about 71 $\%$ in all SBRs. The $\mathrm{NH}_{4}{ }^{+}-\mathrm{N}$ removal efficiency was increased as the increase of aeration time. After changing aeration time, the total nitrogen removal efficiencies of SBRs were shown as 35\%,85\%,75\% and $65 \%$, respectively. Higher phosphorus release and uptake were occurred as the decrease of the aeration time. After all, the overall phosphorus removal efficiency decreased and the deterioration of phosphorus removal was occurred when aeration time was over $4 \mathrm{hr}$. Denitrification in aerobic conditions was observed, which showed the presence of DNPAOs and DNGAOs. In batch experiments, PAOs were shown as the most important microorganisms for the phosphorus removal in this experiment, and the role of DNGAOs was higher than that of DNAPOs for the nitrogen removal.
\end{abstract}

Key Words : SBR, Aeration time, Nutrient removal, PAOs, DNPAOs, DNGAOS, Batch experiment

\section{1. 서 론}

가정 하수, 산업 폐수 또는 축산폐수 등에 포함되어 있는 질소와 인은 호소나 내해와 같은 폐쇄성 수역에

\footnotetext{
${ }^{*}$ Corresponding author : Dongseog Kim, Department of Environmental Science, Catholic University of Daegu, Gyeongbuk 712-702, Korea

Phone: $+82-53-850-3250$

E-mail: kimds@cu.ac.kr
}

서 부영양화를 유발할 수 있으므로 수중의 질소와 인 은 반드시 적절하게 제거되어야 한다. 수중의 질소와 인은 화학적인 방법이나 생물학적인 방법에 의해 제 거될 수 있으나, 경제적인 관점에서 볼 때 생물학적 방 법이 가장 타당한 것으로 인식되고 있다(EPA, 1993; Kim과 Cho, 2006).

특히, 소규모 오수처리시설의 경우, 오수는 유량의 변동이 심하고 $\mathrm{C} / \mathrm{N}$ 비가 낮은 특성을 가지고 있고, 전 
문적인 관리 인력과 자동화 운전 설비의 부재로 인하 여 $\mathrm{pH}$ 나 $\mathrm{DO}$ 와 같은 운전 인자의 조절이 어려울 뿐만 아 니라 적절한 슬러지의 배출이 곤란하여 저조한 질소 - 인 처리효율을 나타내고 있다. 이러한 소규모로 운영되는 생물학적 질소·인 제거 공정으로는 SBR (sequencing batch reactor)이 자주 이용되고 있다(Jeon과 Park, 2000; 박과김, 2007; 박 등, 2007; 김과박, 2010).

$\mathrm{SBR}$ 공정은 혐기, 호기, 무산소 단계를 거쳐 유기 물, 질소 및 인 등을 제거하므로 혐기, 호기 및 무산소 단계의 시간 설정은 매우 중요한 운전 인자라고 할 수 있다. 특히, 호기 단계에서는 다양한 미생물들에 의해 하수 내 유기물의 호기적 분해, 질산화, 인의 과잉 섭 취 등이 발생하므로, $\mathrm{SBR}$ 에서 호기 단계는 매우 중요 한 단계라고 할 수 있다. 또한, 호기 단계에서는 포기 에 의해 사용되는 동력비가 전체 단계에서 가장 크므 로, 호기 단계를 적절하게 조절하여 최적화할 수 있으 면 전체적인 동력비의 절감을 가져 올 수 있다.

그러므로 본 연구에서는 1 차 비포기/포기/2차 비포 기로 운영되는 SBR에서 포기 시간의 변화에 따른 유 기물, 질소 및 인 제거 효율의 변화를 알아보기 위하 여, 초기 1 차 비포기 시간은 일정하게 유지한 상태에 서 포기 시간을 1 시간, 2 시간 30 분, 4 시간, 5 시간 30 분 으로 변화시킴으로써 포기 시간과 2차 비포기 시간을 변화시켜 실험시간 경과에 따른 질소와 인 제거 변화를 거시적으로 관찰하였다. 또한, 포기 시간 변화에 따른 SBR 내 질소와 인의 변화를 미시적 관점에서 관찰함으 로써 포기 시간 변화에 따른 질소와 인 제거 변화에 대 한 근본적인 접근과 해석을 통하여 처리 공정 제어 자동 화 및 효율화를 위한 기초 자료로 제공하고자 한다.

\section{2. 재료 및 방법}

\section{1. 실험재료}

본 실험에 사용된 합성폐수는 Table 1 과 같이 구성
되었다.

Table 1. Compounds and concentrations of synthetic wastewater

\begin{tabular}{cc}
\hline Compounds & Concentration $(\mathrm{mg} / \ell)$ \\
\hline \hline Glucose & $200.0 \mathrm{mg} / \ell$ \\
$\mathrm{MgSO}_{4} \cdot 7 \mathrm{H}_{2} \mathrm{O}$ & $20.0 \mathrm{mg} / \ell$ \\
$\mathrm{MnSO}_{4} \cdot 7 \mathrm{H}_{2} \mathrm{O}$ & $22.0 \mathrm{mg} / \ell$ \\
$\mathrm{FeSO}_{4} \cdot 7 \mathrm{H}_{2} \mathrm{O}$ & $0.9 \mathrm{mg} / \ell$ \\
$\mathrm{KCl}$ & $2.8 \mathrm{mg} / \ell$ \\
$\left(\mathrm{NH}_{4}\right)_{2} \mathrm{SO}_{4}$ & $75.0 \mathrm{mg} / \ell$ \\
$\mathrm{K}_{2} \mathrm{HPO}_{4}$ & $67.0 \mathrm{mg} / \ell$ \\
$\mathrm{NaHCO}_{3}$ & $120.0 \mathrm{mg} / \ell$ \\
$\mathrm{CaCl}_{2}$ & $1.5 \mathrm{mg} / \ell$ \\
\hline
\end{tabular}

\section{2. 실험 및 분석방법}

\subsection{1. 실험방법}

본 실험에서는 Fig. 1 과 같이 4 개의 SBR을 설치하 여 운전하였다. 각 SBR 반응조는 아크릴을 사용하여 $150 \times 150 \times 250 \mathrm{~mm}$ 의 직육면체 크기로 제작되었으며, 유입 후 최대 용적량을 $4 \mathrm{~L}$, 유출 후 최소 용적량이 2 $\mathrm{L}$ 가 되도록 하였다. 슬러지는 $\mathrm{G}$ 시 하수처리장의 반송 슬러지를 실험실내에서 6개월 이상 운전하여 BNR (biological nutrient removal) 슬러지로 전환시켰으며, 본 실험에서는 적응된 $\mathrm{BNR}$ 슬러지를 일부 채취하여 사용하였다. SBR은 연속적인 시간의 흐름에 따라 1 차 비포기/포기 $/ 2$ 차 비포기 조건하에 운전되었다. 반 응기들은 유입 30 분을 포함한 3 시간 30 분의 비포기 구간, 7 시간의 포기/비포기, 각각 30 분의 침전, 유출, 휴지 기간을 거쳐 총 12 시간을 1 주기로 운영되었다 (Table 2).

Table 2. Operation time schedule in SBRs

\begin{tabular}{|c|c|c|c|c|c|c|c|}
\hline & Influent & 1st non-aeration & aeration & 2nd non-aeration & settle & draw & idle \\
\hline R1 & \multirow{4}{*}{$0.5 \mathrm{~h}$} & \multirow{4}{*}{$3.0 \mathrm{~h}$} & $1.0 \mathrm{~h}$ & $6.0 \mathrm{~h}$ & \multirow{4}{*}{$0.5 \mathrm{~h}$} & \multirow{4}{*}{$0.5 \mathrm{~h}$} & \multirow{4}{*}{$0.5 \mathrm{~h}$} \\
\hline $\mathrm{R} 2$ & & & $2.5 \mathrm{~h}$ & $4.5 \mathrm{~h}$ & & & \\
\hline R3 & & & $4.0 \mathrm{~h}$ & $3.0 \mathrm{~h}$ & & & \\
\hline $\mathrm{R} 4$ & & & $5.5 \mathrm{~h}$ & $1.5 \mathrm{~h}$ & & & \\
\hline
\end{tabular}




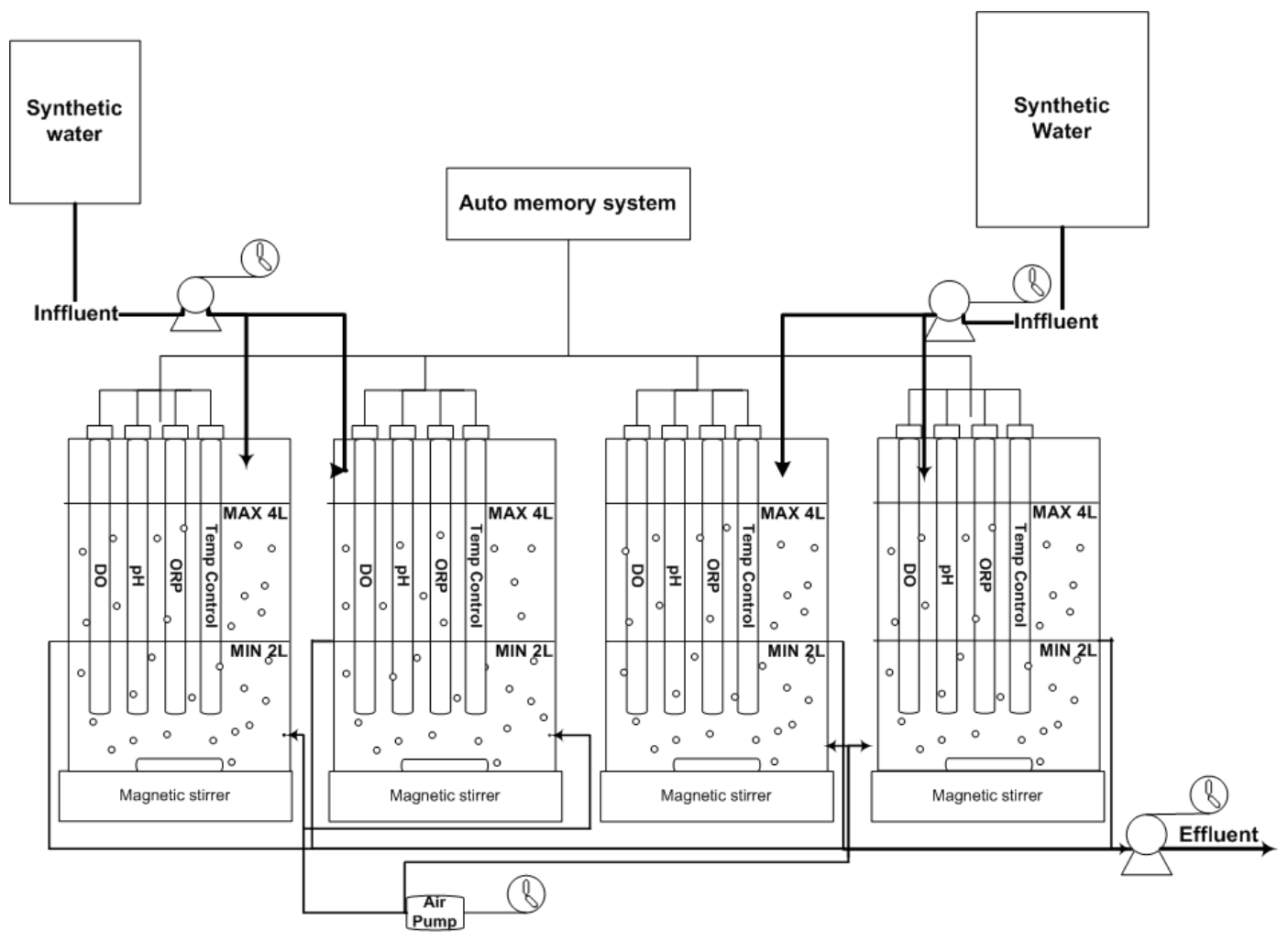

Fig. 1. Schematic diagram of $\mathrm{A}_{2} \mathrm{O}$ SBRs.

1 주기 운전 후에 $2 \mathrm{~L}$ 의 유출수는 같은 양의 유입수로 대체되었고, 수리학적 체류시간 (hydraulic retention time, HRT)은 $24 \mathrm{hr}$ 로 운전되었다. 비포기시 반응기 내 혼합을 위해 반응기 하부에 자석 교반기를 설치하 여 $150 \mathrm{rpm}$ 으로 일정하게 교반시켰으며, 온도는 자동 온도 조절기를 이용하여 $25 \pm 1{ }^{\circ} \mathrm{C}$ 로 유지되었다. 포기 시 공기펌프를 이용하여 $0.5 \mathrm{~L} / \mathrm{min}$ 의 공기를 반응기 하부에 설치된 산기관을 통하여 주입하였다. 기질 공 급, 처리수 배출, 포기 및 혼합 등의 조작은 timer를 이 용하여 제어하였다. $\mathrm{pH}$ 는 인위적으로 조절하지는 않 았으나 운전기간 동안 $\mathrm{pH}$ 는 $6.5 \sim 8.0$ 사이를 유지하였 다. 초기 MLVSS (mixed liquor volatile suspended solids)는 $4,800 \mathrm{mg} / \mathrm{L}$ 로 시작하였다.

\subsection{2. 회분식 실험}

연속 실험을 일시 중단한 상태에서 반응기 내부의 합성 폐수 잔존량을 제거하기 위하여 증류수를 이용
한 세척/침전 과정을 2 회 이상 반복하였다. 합성폐수 의 구성성분들은 원 합성 폐수와 동일하게 유지하거 나 필요에 따라 질소원을 제외한 상태에서 회분식 실 험을 하였으며, 3 시간 30 분의 1 차 비포기 기간이 끝난 직 후 일시적으로 $4 \mathrm{~g} / \mathrm{L} \mathrm{NO}_{3}^{-}-\mathrm{N}$ 의 농축액을 $10 \mathrm{~mL}$ 씩 주입하여 bulk 상태의 $\mathrm{NO}_{3}^{-}-\mathrm{N}$ 농도가 약 $10 \mathrm{mg} / \mathrm{L}$ 가 되도록 하였다. 3 시간 30 분의 1 차 비포기 기간 이후에 는 필요에 따라 포기 단계 또는 2 차 비포기 단계를 수 행하였다.

\subsection{3. 질소와 인 분석방법}

시료는 15 분, 30 분 또는 1 시간 간격으로 채수하였 으며, 채수 즉시 membrane filter $(0.22 \mu \mathrm{m}, \phi 47 \mathrm{~mm})$ 를 이용하여 여과함으로써 시료 내 미생물을 완전히 제거한 다음 분석에 이용하였다. MLVSS는 Standard Methods(Eaton 등, 1995)에 따라 분석하였으며, $\mathrm{NH}_{4}{ }^{+}$ -N은 HS 3100 water analyzer (Humas, Korea)를 사 
용하여 정량 분석하였다. $\mathrm{NO}_{\mathrm{X}}{ }^{-} \mathrm{N}$ 와 $\mathrm{PO}_{4}{ }^{3-}-\mathrm{P}$ 의 정량 분석을 위해 anion column (SUPP4 column, Metrohm)이 부착된 ion chromatograph (Metrohm, Germany)를 사용하였으며, total organic carbon(TOC) 는 TOC analyzer (TOC-5000A, Shimadzu, Japan)를 사용하여 분석하였다.

\section{3. 결과 및 고찰}

\section{1. 초기 BNR 슬러지의 특성}

실험에 사용된 BNR 슬러지의 초기 특성은 Fig. 2 와 같다.

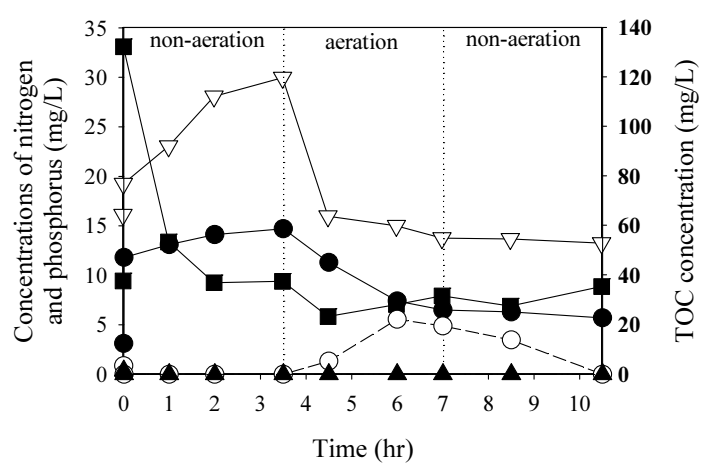

Fig. 2. Nutrient concentrations using BNR sludge ( $\square$ TOC, - $\left.\mathrm{NH}_{4}{ }^{+}-\mathrm{N}, O \mathrm{NO}_{3}{ }^{-}-\mathrm{N}, \boldsymbol{\Delta} \mathrm{NO}_{2}{ }^{-}-\mathrm{N}, \nabla \mathrm{PO}_{4}{ }^{3-}-\mathrm{P}\right)$.

3 시간 30 분의 1 차 비포기 기간동안 $\mathrm{TOC}$ 농도는 약 $135 \mathrm{mg} / \mathrm{L}$ 에서 $40 \mathrm{mg} / \mathrm{L}$ 로 감소하였으며, 이어지는 포기 기간과 2 차 비포기 기간 중에는 TOC 농도의 큰 변화가 발생하지 않았다. 1 차 비포기 기간은 대부분 혐기 기간으로서 인의 방출에 유기물이 이용된 것으 로 판단할 수 있다. 이는 초기 반응기 내 인 농도가 20 $\mathrm{mg} / \mathrm{L}$ 에서 1 차 비포기가 끝나는 시점의 인 농도가 30 $\mathrm{mg} / \mathrm{L}$ 로 증가된 것으로 알 수 있다. 또한, 이 기간 중 $\mathrm{NO}_{3}{ }^{-} \mathrm{N}$ 가 거의 검출되지 않는 것으로 보아 탈질화 반 응이 발생하는 무산소 상태가 아닌 혐기 상태로 판단 할 수 있었다. $\mathrm{NH}_{4}{ }^{+}-\mathrm{N}$ 농도는 변화없이 거의 일정한 농도를 나타내었다.

포기 기간에는 질산화로 인하여 반응조내 $\mathrm{NH}_{4}{ }^{+}-\mathrm{N}$ 농도가 $15 \mathrm{mg} / \mathrm{L}$ 에서 $7 \mathrm{mg} / \mathrm{L}$ 로 감소하였으며 $\mathrm{NO}_{3}{ }^{-}-\mathrm{N}$ 농도는 $0 \mathrm{mg} / \mathrm{L}$ 에서 $5 \mathrm{mg} / \mathrm{L}$ 로 증가하였고 $\mathrm{NO}_{2}{ }^{-}-\mathrm{N}$ 는
거의 검출되지 않았다. 여기서 감소된 $\mathrm{NH}_{4}{ }^{+}-\mathrm{N}$ 농도는 약 $8 \mathrm{mg} / \mathrm{L}$ 인데 비해 생성된 $\mathrm{NO}_{3}{ }^{-} \mathrm{N}$ 농도 약 $5 \mathrm{mg} / \mathrm{L}$ 로 서 다소 많은 차이를 나타내고 있는데, 이는 포기 과정 중 질산화 뿐만 아니라 탈질화가 진행되었다고 판단할 수 있다. 그러므로 본 연구에서는 질산화와 동시에 탈질 화가 발생된 것으로 보고 계속적인 실험을 수행하였다. 이 과정의 탈질화는 DNPAOs (denitrifying phosphorus accumulating organisms)와 DNGAOs (denitrifying glycogen accumulating organisms)에 의하여 발생한 것으로 볼 수 있으며 이에 대한 검증 결과는 회분식 실 험을 통해 Fig. 10에 나타내었다. DNPAOs는 인을 과잉 축적하는 능력을 지닌 PAOs (phosphorus accumulating organisms) 중에서 특이하게 산소 대신 $\mathrm{NO}_{3}{ }^{-}$나 $\mathrm{NO}_{2}{ }^{-}$ 를 전자 수용체로 사용하고 동시에 인을 축적할 수 있 는 미생물 군집으로서, 세포내 저장된 PHB (polyhydroxy butyrate)를 사용하여 탈질을 함으로써 무산 소 조건에서 추가적인 유기물의 공급이 필요치 않고 탈질과 인의 동시 제거가 가능한 것으로 알려져 있다 (Kishida 등, 2006; Oehmen 등, 2006; Shi와 Lee, 2006; Carvalho 등, 2007; 김과 김, 2007). DNGAOs 는 혐기 구간에서 DNPAOs와 같이 유기물을 PHAs (poly hydroxyalkanoic acids)와 같은 VFAs (volatile fatty acids)로 임시 저장하나, 호기 구간에서 임시 저 장된 PHAs를 glycogen으로 축적 - 저장하면서도 인 흡수는 이루어지지 않는다는 차이점이 있다. 그러나 무산소 구간에서 저장된 기질을 사용하여 탈질을 수 행하는 공통점이 있다(Oehmen 등, 2006).

그러나 본 실험에서 조사한 흥미로운 점은 무산소 상태에서만 탈질화가 이루어진다는 것이 아니라 호기 상태에서도 충분히 탈질화가 발생한다는 점이며, 이 는 Fig. 10 의 회분식 실험을 통하여 검정하였다.

2 차 비포기 기간에서 $\mathrm{TOC}$ 와 $\mathrm{NH}_{4}{ }^{+}-\mathrm{N}$ 농도의 변화 는 거의 발생하지 않았고 $\mathrm{PO}_{4}{ }^{3-}-\mathrm{P}$ 농도는 약간 감소하 였으나 그 변화는 그다지 크지 않았다. 그러나 $\mathrm{NO}_{3}{ }^{-}-\mathrm{N}$ 농도는 $6 \mathrm{mg} / \mathrm{L}$ 에서 $0 \mathrm{mg} / \mathrm{L}$ 로 감소하여 탈질화가 발 생하였다는 것을 알 수 있었다. 이 기간 동안 TOC 농 도가 $40 \mathrm{mg} / \mathrm{L}$ 로 낮을 뿐만 아니라 TOC 농도 변화가 거의 없어 일반적인 종속영양 탈질화로 보기에는 무 리가 있었다. 그러므로 이 기간의 탈질화 또한 DNPAOs나 DNGAOs에 의한 탈질화로 생각해 볼 여 
지가 있었다.

\section{2. 포기시간 변동에 따른 유기물 제거 변화}

Fig. 2와 같은 특성을 가진 BNR 슬러지를 이용하 여 포기 시간을 각각 1 시간, 2 시간 30 분, 4 시간, 5 시간 30 분으로 변화시킨 4 개의 SBR을 운전하였으며, 각 SBR내 TOC 농도 변화를 Fig. 3 에 나타내었다.

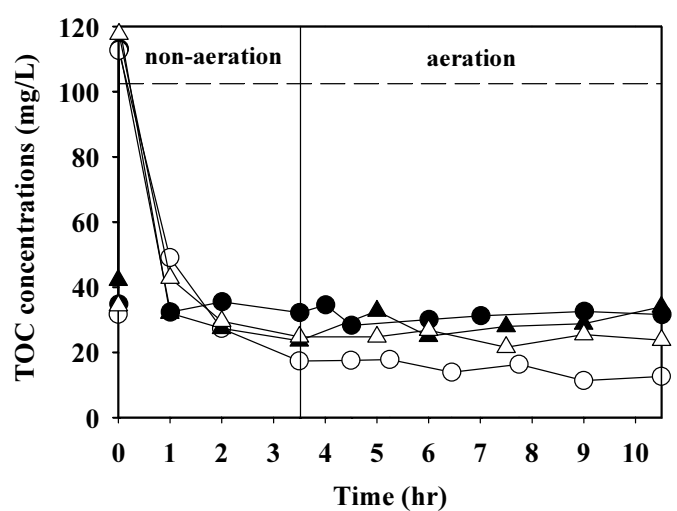

Fig. 3. TOC concentration in $\mathrm{A}_{2} \mathrm{O} \operatorname{SBR}(\bigcirc \mathrm{R} 1, \bigcirc \mathrm{R} 2$, R3, $\triangle$, R4).

합성폐수 유입 직후 SBR 내 초기 TOC 농도는 약 $120 \mathrm{mg} / \mathrm{L}$ 로 유지되었으며, 이 후 SBR 반응기에서의 TOC 농도는 Fig. 3 에서 보는 바와 같이 3 시간 30 분의 1 차 비포기 조건에서 대부분 제거되었다. 실험 초기 포기 시간을 3 시간 30 분으로 유지한 BNR 슬러지의 유기물 제거 효율은 약 $78 \%$ 로 나타났다. 포기 시간을 각각 1 시간, 2 시간 30 분, 4 시간, 5 시간 30 분으로 변경 한 이후의 TOC 제거 효율은 큰 차이를 나타내지 않았 다 (Fig. 4). 유입된 유기물은 1차 비포기 기간에서 네 반응기 모두 $71 \%$ 이상 제거되었다. 유입된 유기물이 1 차 비포기 조건에서 대부분 소모되고 이후 이어지는 포기 $/ 2$ 차 비포기 구간에서 TOC 농도의 변화가 거의 나타나지 않았는데 (Fig. 3), 이는 초기 실험에 사용된 BNR 슬러지 (Fig. 2)와 유사한 특성을 나타내었으며, 포기 시간을 최소 1 시간에서 최대 5 시간 30 분으로 변 경하더라도 유기물의 제거에는 큰 영향이 없다는 것 을 알 수 있었다.

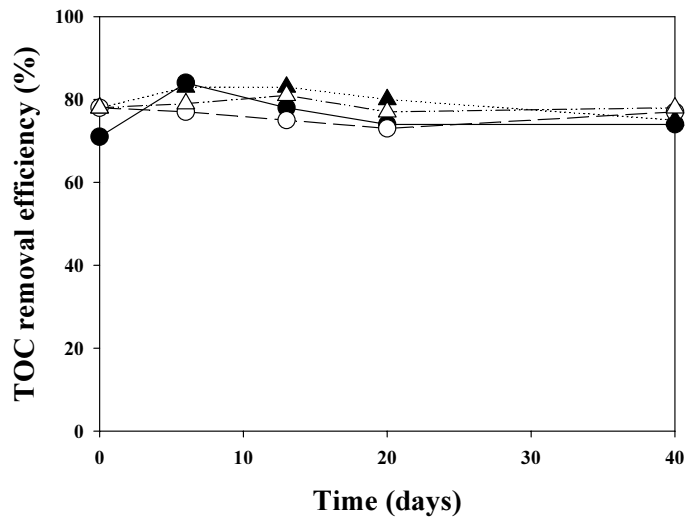

Fig. 4. Variation of TOC removal efficiency by the change of aeration time ( $\bigcirc \mathrm{R} 1, \bigcirc \mathrm{R} 2, \boldsymbol{\Delta} \mathrm{R} 3, \triangle \mathrm{R} 4)$.

\section{3. 포기 시간 변동에 따른 질소제거 변화}

포기 시간의 변동에 따른 $\mathrm{NH}_{4}{ }^{+}-\mathrm{N}$ 제거효율은 Fig. 5 와 같이 나타났다. 4 개의 반응기 모두 실험 초기 $70 \%$ 이상의 $\mathrm{NH}_{4}{ }^{+}-\mathrm{N}$ 제거효율을 나타내었으나, 포기 시간 의 변화에 따라 $\mathrm{NH}_{4}{ }^{+}-\mathrm{N}$ 제거효율은 감소 또는 증가하 는 경향을 나타내었다. 포기 시간을 1 시간으로 변경한 $\mathrm{R} 1$ 에서는 포기 시간 변경 6 일 후 $\mathrm{NH}_{4}{ }^{+}-\mathrm{N}$ 제거효율이 $33 \%$ 로 급격히 감소하였고, 이 후 $\mathrm{NH}_{4}{ }^{+} \mathrm{N}$ 제거효율 은 실험이 종료되는 시점까지 큰 변화가 없이 저조한 것으로 나타났다.

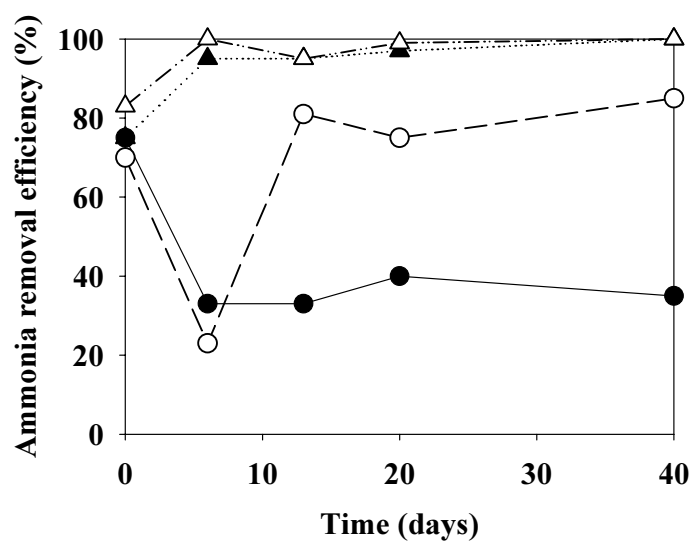

Fig. 5. Variation of ammonia removal efficiency by the change of aeration time ( R1, $\bigcirc \mathrm{R} 2, \boldsymbol{\Delta} \mathrm{R} 3, \triangle$ R4). 
$\mathrm{R} 1$ 에서 전체 실험 기간 동안의 1 주기 질소 변화를 미시적으로 관찰하여 Fig. 6에 나타내었다. 포기 시간 이 1 시간으로 매우 짧아서 $\mathrm{NH}_{4}{ }^{+}-\mathrm{N}$ 의 질산화에 의한 제거 효율이 $10 \%$ 이내로 적게 발생하였으며 그에 따 라 $\mathrm{NO}_{2}^{-}-\mathrm{N}$ 과 $\mathrm{NO}_{3}^{-}-\mathrm{N}$ 의 발생이 적어 거의 검출되지 못하였다. 낮은 질산화 효율로 인하여 $\mathrm{NO}_{2}-\mathrm{N}$ 과 $\mathrm{NO}_{3}^{-}-\mathrm{N}$ 가 낮은 농도로라도 검출되어야 함에도 불구 하고 전혀 검출되지 않은 것은 Fig. 2에서 언급한 바와 같이 이 과정 중에 DNGAOs와 DNPAOs에 의해 탈질 화가 동시에 발생하여 $\mathrm{NO}_{2}^{-}-\mathrm{N}$ 과 $\mathrm{NO}_{3}^{-}-\mathrm{N}$ 가 탈질화되 어 제거되었기 때문인 것으로 판단된다.

포기 시간이 2 시간 30 분인 R2의 경우, 포기 시간 변경 후 6일이 경과된 시점에서 $\mathrm{NH}_{4}{ }^{+}-\mathrm{N}$ 제거효율이 $\mathrm{R} 1$ 보다 낮은 $23 \%$ 를 나타내었으나, 16 일 이후부터는 제거효율이 회복되어 $75 \%$ 이상의 $\mathrm{NH}_{4}{ }^{+} \mathrm{N}$ 제거효율 을 나타내었다 (Fig. 5). 미시적 관찰결과를 살펴보면 (Fig. 7), 초기 6일에는 거의 질산화가 발생되지 못함 으로써 $\mathrm{NH}_{4}{ }^{+}-\mathrm{N}$ 농도의 감소도 적었고 $\mathrm{NO}_{2}^{-}-\mathrm{N}$ 과 $\mathrm{NO}_{3}^{-}-\mathrm{N}$ 도 거의 발생하지 않았다. 미처리된 $\mathrm{NH}_{4}{ }^{+}-\mathrm{N}$ 가 잔존하여 유입수와 합쳐짐으로써 초기 $\mathrm{NH}_{4}{ }^{+} \mathrm{-N}$ 농도 가 $30 \mathrm{mg} / \mathrm{L}$ 까지 높아지기도 하였다. 그러나 13 일이 경과됨에 따라 실험 조건에 적응하기 시작함에 따라 질산화가 적절하게 발생하기 시작하였고 그에 따라 $\mathrm{NH}_{4}{ }^{+} \mathrm{N}$ 농도의 감소와 $\mathrm{NO}_{3}{ }^{-}-\mathrm{N}$ 농도의 증가가 포기 기간 동안 발생하였다. $\mathrm{NO}_{2}-\mathrm{N}$ 는 거의 검출되지 않았 다. 발생된 $\mathrm{NO}_{3}^{-}-\mathrm{N}$ 는 2차 비포기 기간 동안 탈질화에 의해 제거되었다. 반응기내 초기 $\mathrm{NH}_{4}{ }^{+} \mathrm{-N}$ 농도 또한 감 소하여 $15 \pm 2 \mathrm{mg} / \mathrm{L}$ 를 나타내었다. 그러나 완전한 질산 화는 발생하지 않았으며 그에 따라 한 주기 마지막 부 분에서는 $5 \mathrm{mg} / \mathrm{L}$ 이상의 $\mathrm{NH}_{4}{ }^{+} \mathrm{N}$ 농도가 항상 잔존하 였다. 그러므로 본 실험에서 포기 시간 2 시간 30 분은 완전한 질산화를 위해서는 부족하다고 판단되었다.

$\mathrm{R} 3$ 과 R4에서는 포기 시간을 4 시간과 5 시간 30 분 으로 각각 변경함에 따라 $\mathrm{NH}_{4}{ }^{+} \mathrm{-N}$ 제거효율이 증가하 여 지속적으로 $95 \%$ 이상의 $\mathrm{NH}_{4}{ }^{+} \mathrm{N}$ 제거효율을 나타 내었다 (Fig. 5). 반응기내 $\mathrm{NH}_{4}{ }^{+}-\mathrm{N}$ 는 포기 조건에서 유입 $\mathrm{NH}_{4}{ }^{+} \mathrm{N}$ 에 대한 질산화가 활발히 이루어짐에 따 라 낮은 농도로 일정하게 유지되었다. R3와 R4의 $\mathrm{NH}_{4}{ }^{+} \mathrm{-N}$ 제거 속도는 거의 동일하여 포기 시간 4 시간 이 경과하는 시점에서 대부분의 $\mathrm{NH}_{4}{ }^{+}-\mathrm{N}$ 가 제거되는
것으로 나타났다 (Fig. 8, 9). R4에서는 과도한 질산화 로 인하여 시간이 경과됨에 따라 생성되는 $\mathrm{NO}_{3}-\mathrm{N}$ 농 도가 증가하였고 2 차 비포기 기간 중 잔존하는 $\mathrm{NO}_{3}^{-}-\mathrm{N}$ 농도가 증가하는 경향을 나타내었는데, 이는 포기 기간 중 DNPAOs나 DNGAOs에 의해 탈질이 발 생할 수 있으나, 포기 시간이 길어짐에 따라 질산화가 활발하게 일어나고 오히려 탈질화는 위축되었기 때문 인 것으로 판단되었다.

암모니아 산화로 인해 생성되는 $\mathrm{NO}_{\mathrm{x}}{ }^{-} \mathrm{N}$ 은 일반적 으로 유기물에 의한 종속영양탈질로 $\mathrm{N}_{2} \mathrm{O}$ 를 거쳐 $\mathrm{N}_{2}$ 로 제거된다. 본 연구에서는 4 개의 반응기 모두 초기 3 시간 이내의 1 차 비포기 기간에 대부분의 유기물이 제 거되었고 이후 유기물의 농도 변화가 발생하지 않았 기 때문에 2차 비포기 기간 중 제거된 $\mathrm{NO}_{\mathrm{x}}^{-}-\mathrm{N}$ 는 외부 탄소원에 의한 종속영양탈질이 아닌 것으로 판단되었 다 (Fig. 6 9). 또한 일반적인 탈질 반응을 위한 용존 산소 농도가 $0.2 \mathrm{mg} / \mathrm{L}$ 이하임에도 불구하고 (Dawson 과 Murphy, 1972), 본 실험에서는 $2 \mathrm{mg} / \mathrm{L}$ 이상의 용존 산소 농도에서도 탈질 현상이 관찰되었다 (Fig. 10).

$\mathrm{R} 1$ 은 포기 구간에서 $\mathrm{NH}_{4}{ }^{+}-\mathrm{N}$ 가 제거됨에도 불구하 고 $\mathrm{NO}_{\mathrm{x}}{ }^{-} \mathrm{N}$ 가 검출되지 않았으며, $\mathrm{R} 2$ 도 $\mathrm{NH}_{4}{ }^{+}-\mathrm{N}$ 의 산 화된 양에 비해 $\mathrm{NO}_{3}^{-}-\mathrm{N}$ 의 양이 적게 검출되었다. 이는 $\mathrm{R} 1$ 과 R2에 있어서는 $\mathrm{NH}_{4}{ }^{+}-\mathrm{N}^{-}$가 $\mathrm{NO}_{2}^{-}-\mathrm{N}^{-}$나 $\mathrm{NO}_{3}^{-}-\mathrm{N}$ 로 전환된 후 포기 구간에서도 탈질이 이루어졌기 때문 인 것으로 판단된다. R3과 R4는 포기 기간 동안 높은 $\mathrm{DO}$ 농도를 나타내며 포기 기간 내내 높은 $\mathrm{NO}_{2}^{-}-\mathrm{N}$ 및 $\mathrm{NO}_{3}{ }^{-} \mathrm{-N}$ 의 농도를 나타내었으나, 산화되는 $\mathrm{NH}_{4}{ }^{+} \mathrm{N}$ 농 도에 비해 $\mathrm{NO}^{-}-\mathrm{N}$ 의 양이 다소 적게 검출되는 경향이 있었는데, 이 또한 R1과 R2의 경우와 유사한 포기 기 간의 탈질현상으로 볼 수 있었다.

Fig. 6 9에서 나타난 포기 기간 중의 탈질 현상들을 확인하기 위하여 회분식 실험을 수행하였다 (Fig. 10). $\mathrm{R} 2$ 에서 연속적인 실험을 일시 중단한 상태에서 반응 기 내부의 합성 폐수 잔존량을 제거하기 위하여 증류 수를 이용한 세척-침전 과정을 2 회 이상 반복하였다. 질소원을 제외한 다른 구성성분들은 원 합성 폐수와 동일하게 유지한 상태에서 회분식 실험을 하였으며, 3 시간 30 분의 비포기가 끝난 직후 일시적으로 고농도 의 $\mathrm{NO}_{3}^{-} \mathrm{-}$ 를 주입하여 bulk 상태의 $\mathrm{NO}_{3}^{-}-\mathrm{N}$ 농도가 10 $\mathrm{mg} / \mathrm{L}$ 가 되도록 하였다. 고농도 $\mathrm{NO}_{3}{ }^{-} \mathrm{-N}$ 의 유입에 의 


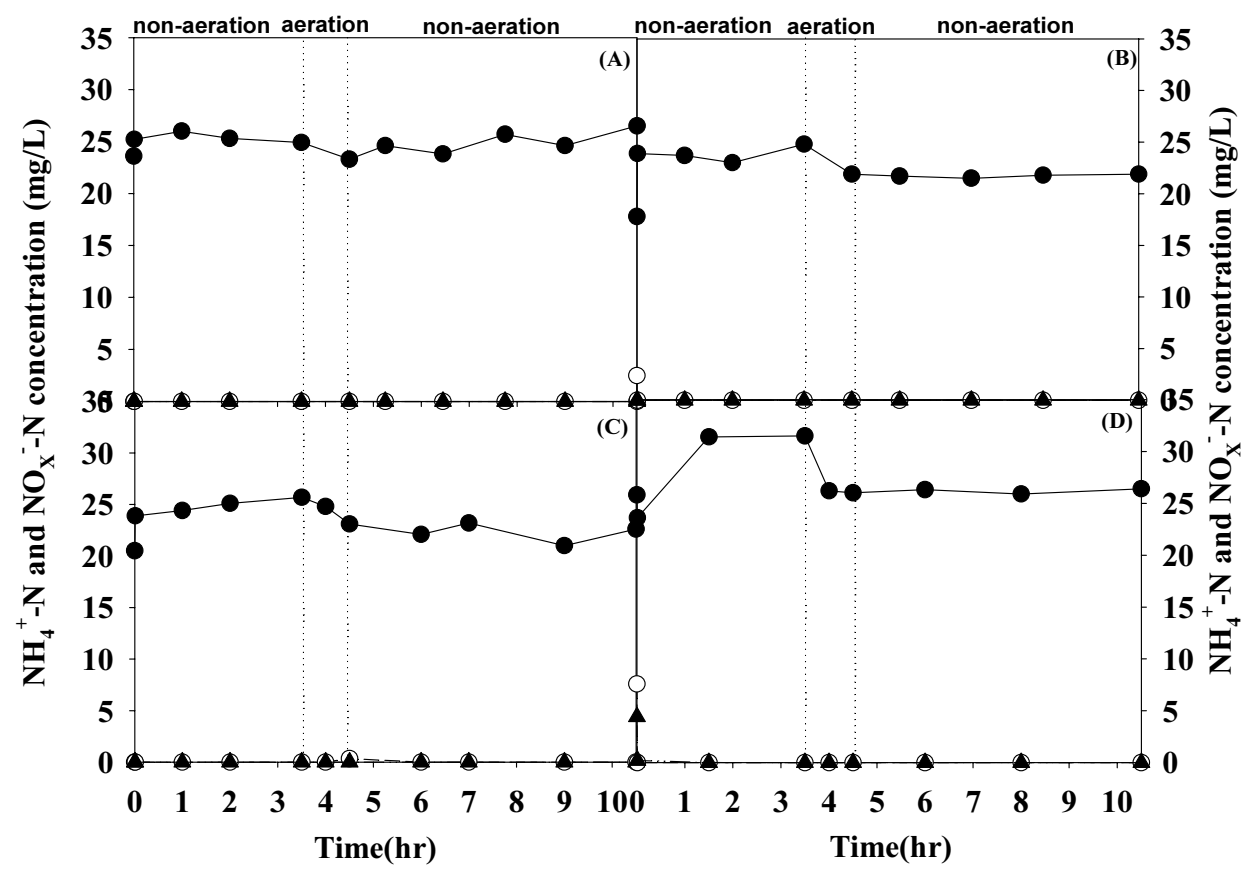

Fig. 6. Variation of $\mathrm{NH}_{4}{ }^{+}-\mathrm{N}$ and $\mathrm{NO}_{\mathrm{x}}{ }^{-}-\mathrm{N}$ concentration according to the elapsed time ((A) 6 days, (B) 13 days, (C) 20 days, (D)40 days) in $\mathrm{R} 1\left(\mathrm{NH}_{4}{ }^{+}-\mathrm{N}, \bigcirc \mathrm{NO}_{3}^{-}-\mathrm{N}, \boldsymbol{\Delta} \mathrm{NO}_{2}^{-}-\mathrm{N}\right)$.

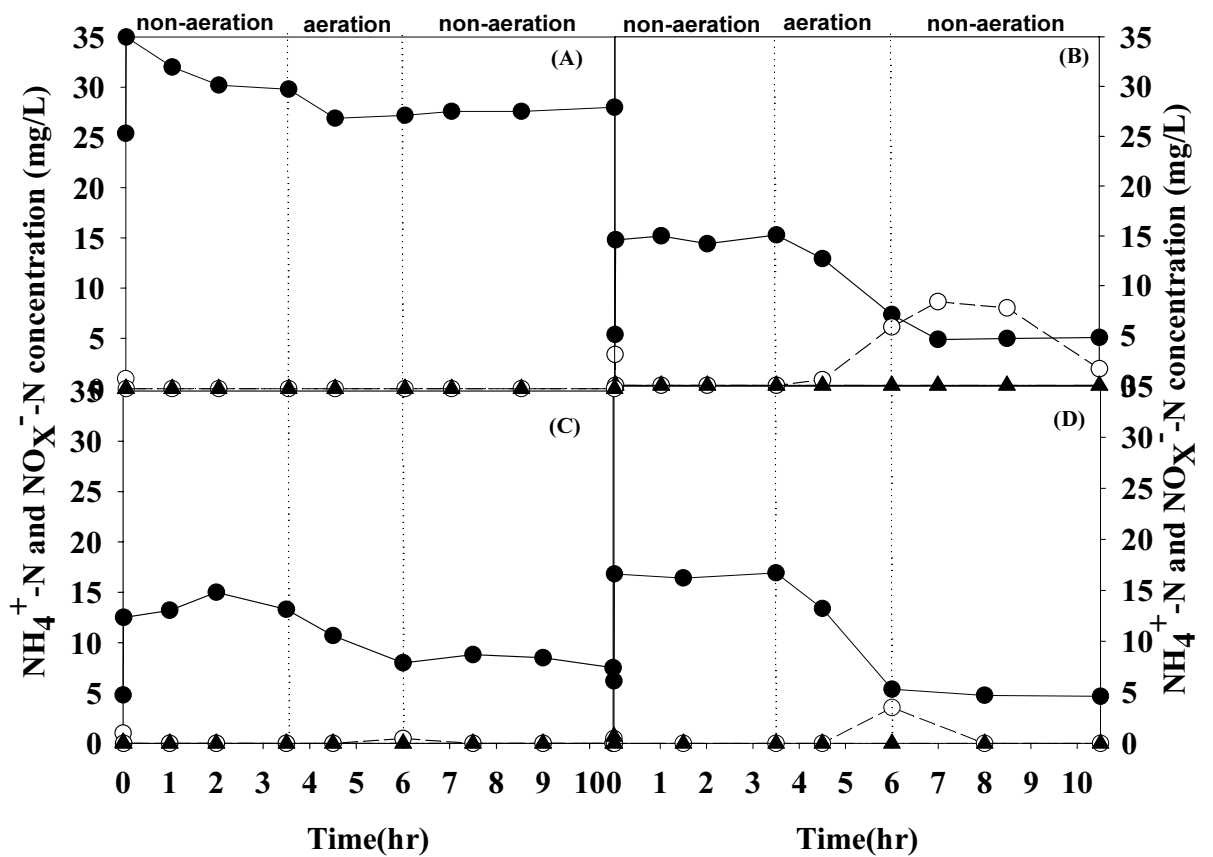

Fig. 7. Variation of $\mathrm{NH}_{4}{ }^{+}-\mathrm{N}$ and $\mathrm{NO}_{\mathrm{x}}{ }^{-}-\mathrm{N}$ concentration according to the elapsed time ((A) 6 days, (B) 13 days, (C) 20 days, (D) 40 days) in $\mathrm{R} 2\left(\mathrm{NH}_{4}{ }^{+}-\mathrm{N}, \bigcirc \mathrm{NO}_{3}{ }^{-}-\mathrm{N}, \boldsymbol{\Delta} \mathrm{NO}_{2}{ }^{-}-\mathrm{N}\right)$. 


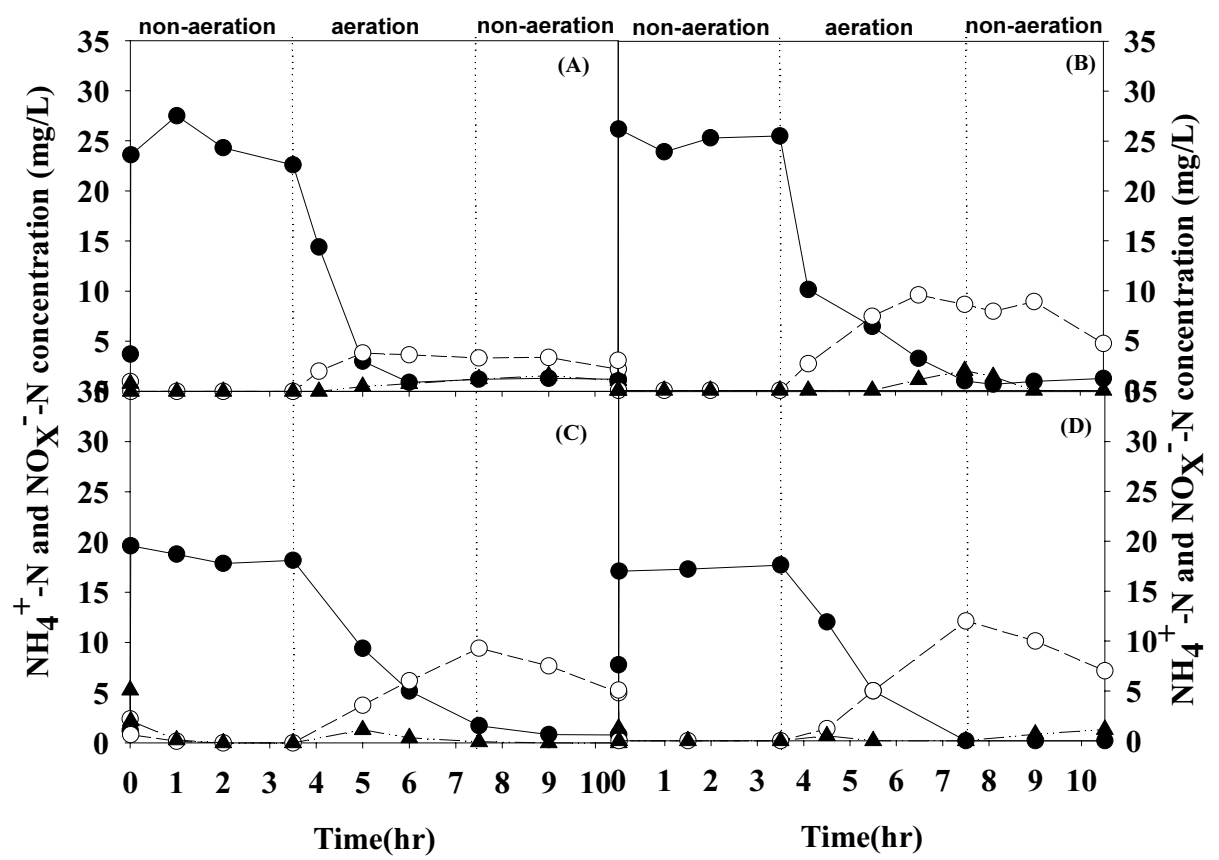

Fig. 8. Variation of $\mathrm{NH}_{4}{ }^{+}-\mathrm{N}$ and $\mathrm{NO}_{\mathrm{x}}{ }^{-}-\mathrm{N}$ concentration according to the elapsed time

((A) 6 days, (B) 13 days, (C) 20 days, (D) 40 days) in $\mathrm{R} 3\left(\mathrm{NH}_{4}{ }^{+}-\mathrm{N}, \circ \mathrm{NO}_{3}^{-}-\mathrm{N}, \boldsymbol{\Delta} \mathrm{NO}_{2}^{-}-\mathrm{N}\right)$.

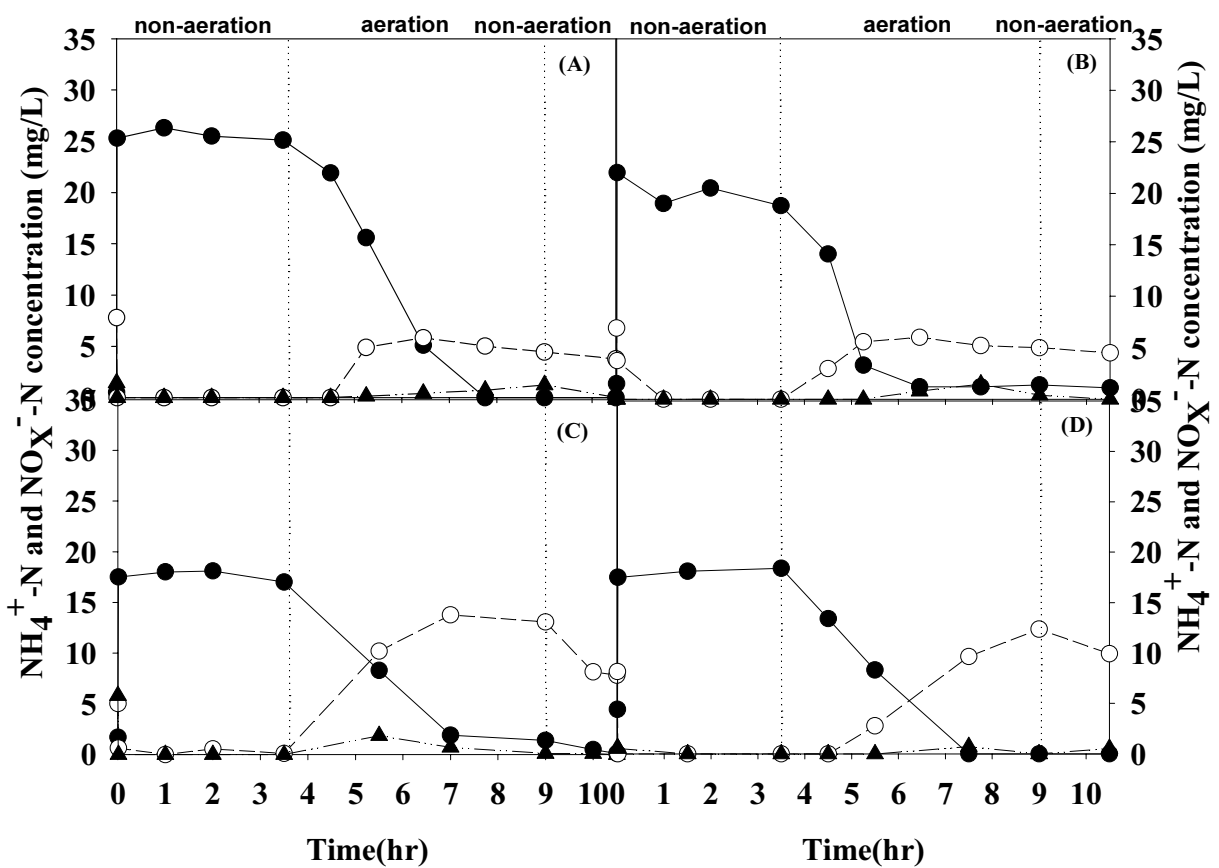

Fig. 9. Variation of $\mathrm{NH}_{4}{ }^{+}-\mathrm{N}$ and $\mathrm{NO}_{\mathrm{x}}{ }^{-} \mathrm{N}$ concentration according to the elapsed time ((A) 6 days, (B) 13 days, (C) 20 days, (D) 40 days) in $\mathrm{R} 4\left(\boldsymbol{O} \mathrm{NH}_{4}{ }^{+}-\mathrm{N}, \bigcirc \mathrm{NO}_{3}^{-}-\mathrm{N}, \boldsymbol{\Delta} \mathrm{NO}_{2}^{-}-\mathrm{N}\right)$. 


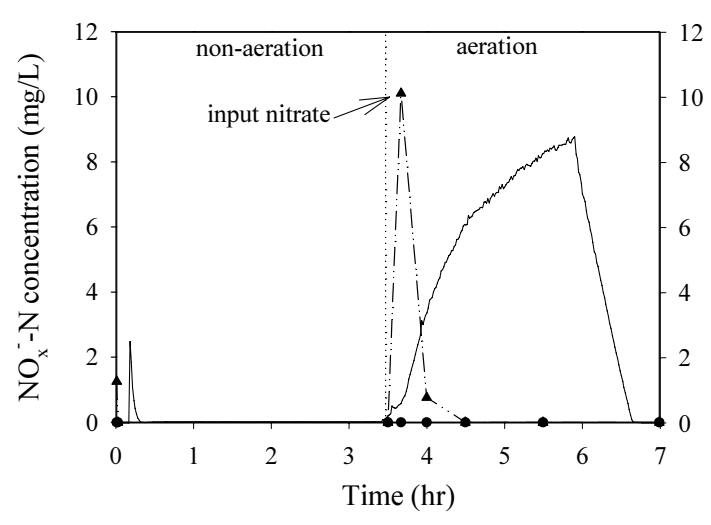

Fig. 10. $\mathrm{DO}$ and $\mathrm{NO}_{\mathrm{x}}^{-}-\mathrm{N}$ concentration in batch experiment ( $\Delta$ nitrate, $\triangle$ nitrite, $-\mathrm{DO}$ ).

해 $\mathrm{NO}_{3}{ }^{-}-\mathrm{N}$ 농도가 일시적으로 증가하였으며, 포기에 의해 $\mathrm{DO}$ 농도가 계속적으로 증가함에도 불구하고 $\mathrm{NO}_{3}{ }^{-}-\mathrm{N}$ 농도가 급격하게 감소하여 1 시간 이내에 거의 $0 \mathrm{mg} / \mathrm{L}$ 로 감소함으로써 호기 상태에서의 탈질화를 관찰할 수 있었다. 이는 무산소 상태의 탈질화와는 차 별화되는 것으로 DNPAOs와 DNGAOs에 의한 탈질 화로 생각해 볼 수 있으며, 앞의 실험 결과들에서 포기 과정 중 질산화되어 감소된 $\mathrm{NH}_{4}{ }^{+}-\mathrm{N}$ 농도에 비해 생성 된 $\mathrm{NO}_{3}^{-}-\mathrm{N}$ 농도가 낮은 것은 본 실험에서와 같은 DNPAOs와 DNGAOs에 의해 탈질화되었기 때문인 것으로 판단된다. 본 연구결과와 같은 호기 탈질화는 슬러지 내에 축적된 PHB (polyhydroxy butyrate)를 전자공여체로 이용할 수 있기 때문에 발생하는 것으 로 다른 연구자들의 연구결과에서도 보고되고 있다 (Bernat와 Wojnowska-Baryla, 2007).

포기 시간 변동에 따른 총 질소 제거효율 변화는 Fig. 11 과 같이 관찰되었다. 질산화와 탈질화에 의한 질소제거효율은 실험 초기 4 개 반응기 각각 $75 \%, 71$ $\%, 75 \%, 83 \%$ 를 나타내었다. 포기 시간 변동 후 R1은 미약한 질산화로 인하여 질소제거효율이 $35 \%$ 로 감 소하였으며, R3와 R4는 포기 시간이 과다하게 많음으 로써 원활한 질산화에 비해 동시 탈질화 효율이 감소 하여 각각 $75 \%$ 와 $65 \%$ 의 질소 제거효율을 나타내었 다. 이에 반해 R2는 2 시간 30 분의 포기 구간동안 85 $\%$ 의 질산화 효율을 나타내었으며, 생성된 $\mathrm{NO}_{\mathrm{X}}^{-}-\mathrm{N}$ 에 대해서는 $100 \%$ 의 탈질효율을 보임으로써, 40 일의
경과 시간에서 전체적인 총 질소제거효율은 $80 \%$ 로서 가장 높은 총 질소 제거효율을 나타내었다. 그러므로 본 실험에서 총 질소제거 측면에서는 포기 시간을 2 시 간 30 분으로 유지하는 것이 적절할 것으로 판단되었다.

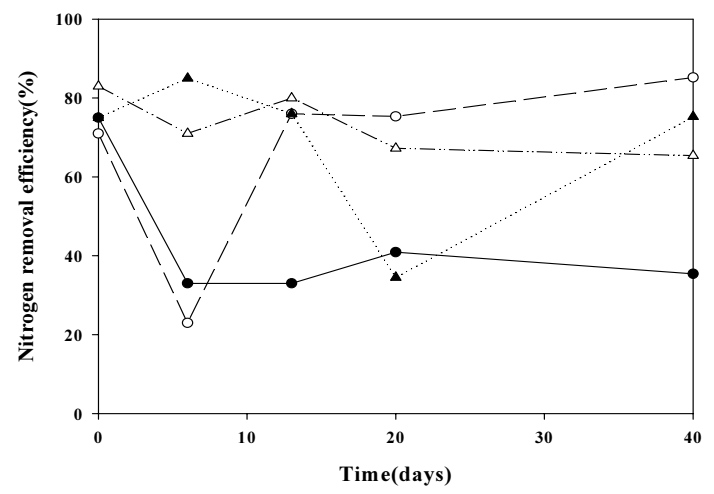

Fig. 11. Variation of total nitrogen removal efficiency by the change of aeration time

R1, O R2,

$\Delta \mathrm{R} 3, \triangle$, R4).

\section{3. 포기 시간 변동에 따른 인 제거 변화}

포기 시간 변동에 따른 인 방출량과 인 흡수량의 변 화를 Fig. 12에 나타내었다.

$\mathrm{R} 1$ 의 경우에는 1 차 비포기 기간 중 인 농도가 22 $\mathrm{mg} / \mathrm{L}$ 에서 $30 \mathrm{mg} / \mathrm{L}$ 로 증가함으로써 $8 \mathrm{mg} / \mathrm{L}$ 의 인 방 출량을 나타내었고 (Fig. 12(a)), 시간이 경과되어 감 소된 포기 시간에 적응해 감에 따라 인 방출량은 증가 되는 경향을 나타내었다. 40 일이 경과된 시점에서 1 차 비포기 구간의 인 방출량은 약 $19 \mathrm{mg} / \mathrm{L}$ 로 나타났 다. R2에서도 시간이 경과됨에 따라 인 방출이 증가하 는 경향을 나타내었다. 그러므로 기존 3 시간 30 분으 로 설정되어 운전한 슬러지를 각각 1 시간과 2 시간 30 분으로 감소시킴에 따라 인의 방출량은 증가하였다. 그러나 포기 시간을 기존 3 시간 30 분보다 많은 4 시간 과 5 시간 30 분으로 각각 변화시킨 R3와 R4에서는 전 자와는 다른 인 방출 경향이 발생하였다. 실험시간이 경과될수록 1 차 비포기 기간 중 방출되는 인의 양은 감소하는 경향을 나타내었고, R3의 경우 40 일이 경과 된 시점에서의 방출된 인의 양은 $5 \mathrm{mg} / \mathrm{L}$ 를 초과하지 못하였다. 포기 시간을 4시간을 한 R3의 경우보다는 포기 시간을 5 시간 30 분으로 한 R4의 경우에서 인의 


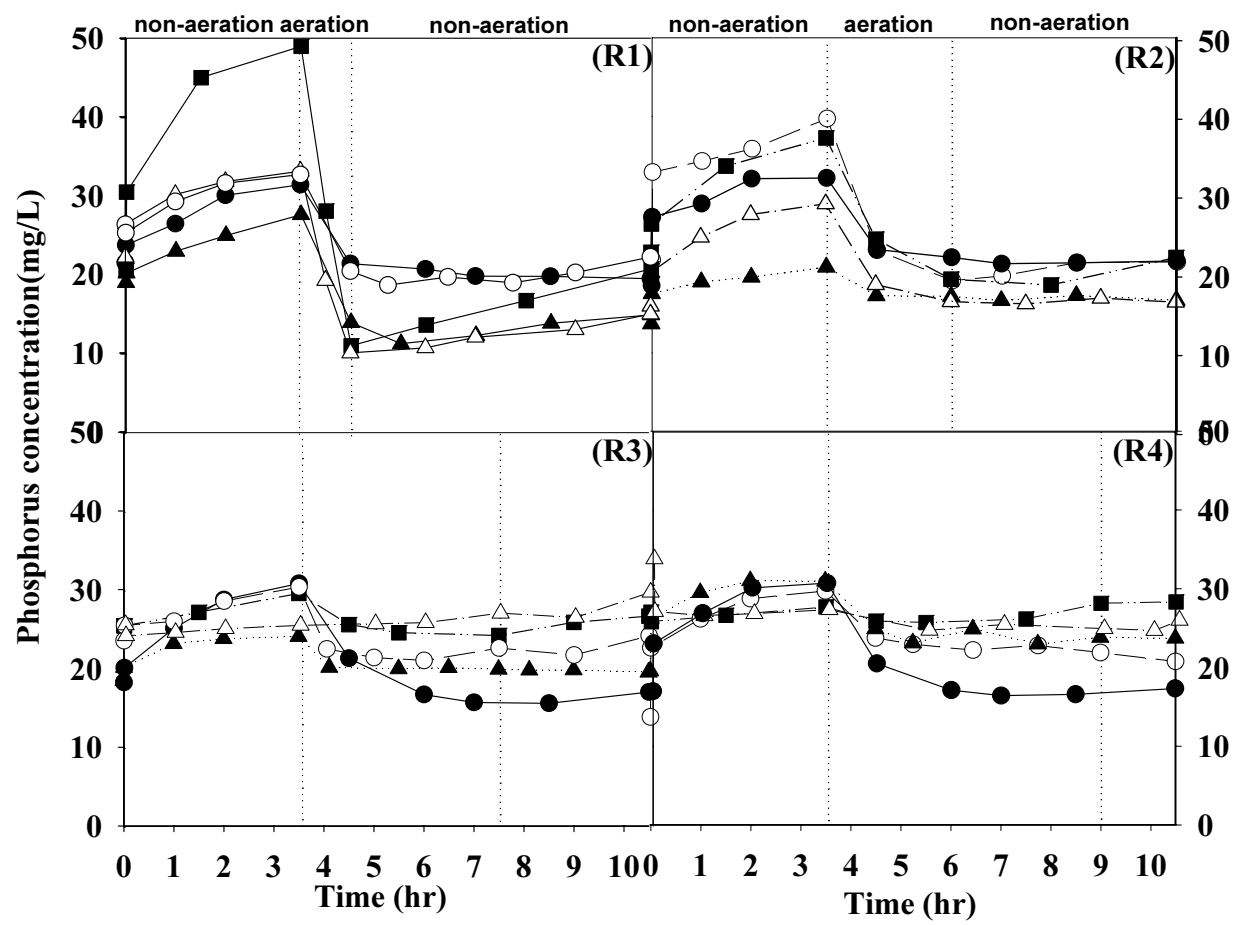

Fig. 12. Variation of phosphorus concentration by the change of aeration time ( 0 days, $\bigcirc$ 6days, $\Delta$ 13days, $\triangle 2$ 20days, $\square 40$ days).

방출량이 더 적게 발생하였다. 그러므로 포기 시간을 증가시킴에 따라 1 차 비포기 과정에도 영향을 미쳐 인 의 방출량을 감소시킨다는 것을 알 수 있었다. 과도한 포기는 과다한 PHB의 소모로 인하여 체내 PHB의 부 족을 초래하게 됨으로써 인 제거에 부정적이라는 보 고가 발표된 바 있었다 (Brdjanovic 등, 1998).

포기 시간이 1 시간으로 가장 짧은 R1의 경우, 실험 기간이 경과됨에 따라 포기 기간 중의 인 흡수량과 인 의 흡수속도가 증가하였다. 초기 인 흡수농도와 인 흡 수속도는 각각 $10 \mathrm{mg} / \mathrm{L}$ 과 $40 \mathrm{mg} / \mathrm{h}$ 였으나 13 일이 경 과된 시점에서의 인 흡수농도과 흡수속도는 각각 16 $\mathrm{mg} / \mathrm{L}$ 와 $64 \mathrm{mg} / \mathrm{h}$ 로 증가하였으며 최종적으로 40 일이 경과된 후에는 각각 $36 \mathrm{mg} / \mathrm{L}$ 와 $144 \mathrm{mg} / \mathrm{h}$ 로 증가하였 다. 포기 시간이 2 시간 30 분인 R2의 경우에는 실험이 경과됨에 따라 약간의 변동은 있었으나 최종적으로 40 일 경과된 시점에는 인 흡수 농도와 흡수 속도는 18 $\mathrm{mg} / \mathrm{L}$ 와 $29 \mathrm{mg} / \mathrm{h}$ 로 증가하였다.

그러나 포기 시간을 3 시간 30 분으로 증가시킨 R3
에서는 인의 흡수농도와 흡수속도가 감소하는 경향을 나타내었고 40 일이 경과된 시점에서의 인 흡수농도와 흡수속도는 각각 $5.3 \mathrm{mg} / \mathrm{L}$ 와 $6.1 \mathrm{mg} / \mathrm{h}$ 로 매우 저조하 게 나타났다. 이는 포기 시간을 증가시키는 것이 인의 흡수에 도움이 되지 못하고 오히려 인의 섭취에 방해 가 된다는 것을 알 수 있다. 또한, 포기 시간을 5 시간 30 분으로 증가시킨 R4에서는 인의 흡수가 거의 발생 하지 못하여 인의 제거 기작이 완전히 파괴되었다는 것을 알 수 있었다.

2 차 비포기 기간에는 모든 반응기에서 대부분 인의 농도변화가 거의 없는 것으로 나타났다.

전체적으로 볼 때, 포기 시간을 증가시킬수록 1차 비포기 기간의 인 방출이 적어지고 그에 따라 포기 기 간의 인 흡수도 불량해 진다는 것을 알 수 있었는데, 이는 인 제거가 질소 제거와 밀접한 관계를 가지기 때 문인 것으로 볼 수 있다.

포기 시간을 증가시킬 경우 질산화 미생물의 활동 이 활발해 짐으로써 Fig. 8과 9에서 보는 바와 같이 
$\mathrm{NO}_{3}{ }^{-}$의 농도가 증가하게 되었고, 증가된 $\mathrm{NO}_{3}{ }^{-}$의 일부 는 DNPAOs나 DNGAOs에 의해 제거되나 일부는 잔 존하여 PAOs의 활동을 억제시킴으로써 인의 흡수가 저해된 것으로 판단된다. 또한 포기 시간이 경과됨에 따라 $\mathrm{NO}_{3}{ }^{-}$의 농도가 증가되고 (Fig. 8과 9) 인의 흡수 가 줄어드는 것 (Fig. 12)으로 보아 지나친 포기는 DNPAOs나 DNGAOs의 활동뿐만 아니라 PAOs의 활동도 억제한다는 것을 알 수 있었다.

또한, 각 반응기내의 존재하는 질소 - 인 제거 미생 물인 PAOs와 DNPAOs 및 DNGAOs의 존재 유무를 확인하기 위하여 회분식 실험을 수행하였으며, 그 결 과는 Fig. 13과 같다.

연속 실험을 일시적으로 중단한 상태에서 반응기 내에 잔존하는 유기물 및 영양염류를 제거하기 위하 여 증류수를 유입수로 투입하여 SBR 운전을 3회 이 상 수행하였다. 반응기내 유기물 및 영양염류가 거의 존재하지 않는다는 것을 확인한 다음, 각 반응기에서 3 시간 30 분의 비포기와 3 시간 30 분의 포기 과정을 수 행하였다. 이 실험이 완료된 다음, 앞 단계에서 수행한 세척과정을 다시 수행하였고 3 시간 30 분의 비포기 시 간과 추가 3 시간 30 분의 비포기 실험을 수행하였다. 이 과정에서는 앞 단계와 같은 방법과 같은 합성폐수 를 사용하였으나, $\mathrm{NO}_{3}{ }^{-}$의 영향을 알아보기 위하여 3 시간 30 분의 비포기 단계가 끝난 다음 $4 \mathrm{~g} / \mathrm{L} \mathrm{NO}_{3}^{-}-\mathrm{N}$ 의 농축액을 $10 \mathrm{~mL}$ 씩 각 반응기에 투입하여 $\mathrm{NO}_{3}{ }^{-} \mathrm{-N}$ 와 인 농도의 변화를 관찰하였다.
비포기와 포기로 진행된 1차 회분식 실험에서는 연 속실험에서와 유사한 실험 결과를 나타내었다. 포기 시간이 1 시간과 2 시간 30 분으로 짧게 유지한 R1과 $\mathrm{R} 2$ 에서는 비포기 기간 중 각각 $13 \mathrm{mg} / \mathrm{L}$ 와 $8 \mathrm{mg} / \mathrm{L}$ 의 인 농도 변화가 발생함으로써 인의 방출이 크다는 것 을 확인할 수 있었으며, 그에 따라 이어지는 포기 단계 에서 R1에서는 2 시간 이내에 인 농도가 거의 $0 \mathrm{mg} / \mathrm{L}$ 에 가깝게 감소함으로써 인의 흡수도 매우 활발하다 는 것을 알 수 있었다. R1에 비해 R2에서는 인 흡수에 의한 제거가 완전히 발생하지는 않았으나 $13 \mathrm{mg} / \mathrm{L}$ 의 인 농도 감소가 발생함으로써 인 흡수도 비교적 원 활하였다. 그러나 포기 시간이 4시간인 R3에서는 비 포기 기간 중 $4.2 \mathrm{mg} / \mathrm{L}$ 의 인 농도 증가와 포기 기간 중 $4.5 \mathrm{mg} / \mathrm{L}$ 의 인 농도 감소가 관찰되어 매우 저조한 인 방출과 인 흡수가 발생하였다. 그러나 포기 시간 5 시간 30 분으로 적응된 R4에서는 비포기 기간 중의 인 방출 과 포기 기간 중의 인 흡수가 거의 관찰되지 않았다.

비포기/포기로 진행된 실험 중에서 제거된 인은 PAOs와 DNPAOs에 의해 제거된 것으로 생각해 볼 수 있으며, 포기 단계에서 동시 질소제거도 발생하였 는데 이는 DNPAOs와 DNGAOs에 의해 제거된 것으 로 판단된다.

비포기와 $\mathrm{NO}_{3}{ }^{-}$가 투입되는 비포기로 운전된 2차 회분식 실험을 수행한 결과, 모든 반응기에서 $\mathrm{NO}_{3}{ }^{-}-\mathrm{N}$ 농도는 1 시간 이내에 $0 \mathrm{mg} / \mathrm{L}$ 로 급격하게 감소함으로 써 원활한 탈질화를 나타내었으나, 인의 흡수는 매우

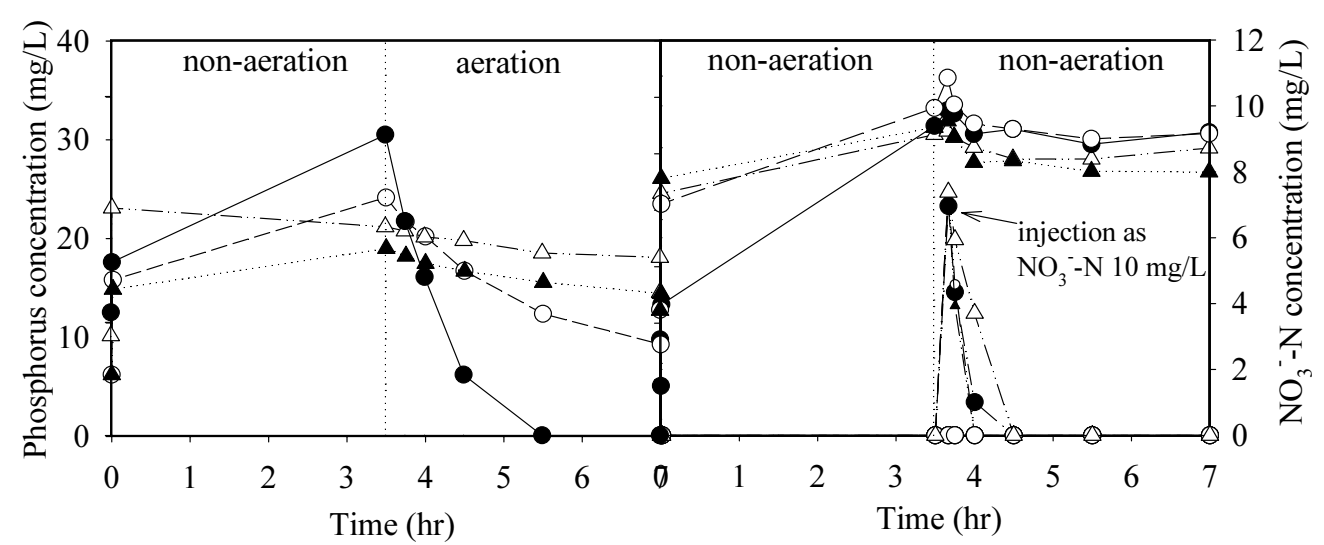

Fig. 13. Variation of phosphorus and nitrate concentrations $(\boldsymbol{R} 1, \bigcirc \mathrm{R} 2, \boldsymbol{\Delta} \mathrm{R} 3, \triangle, \mathrm{R} 4)$. 
저조한 상태를 나타내었다. 이는 호기 상태의 인 흡수 가 무산소 상태의 인 흡수보다 훨씬 크다는 Artan 등 (1998)의 결과와 유사하였다. 또한, nitrate는 인 방출 을 저해하는 것으로 알려져 있으나(Chung 등, 1996), Saito 등(2004)은 nitrite와 nitrate는 모두 PAOs의 인 흡수도 저해하고 그 중 nitrite가 더 큰 저해 작용을 한 다고 발표 한 바 있다. 앞의 여러 실험결과들에서도 알 수 있듯이 이 구간 중 TOC 농도의 감소가 거의 발생 하지 않았으므로 일반적인 탈질화 미생물에 의해 제 거된 것으로 볼 수 없었고, glycogen, PHB 및 poly-P 와 같은 생체내 저장물질을 이용하는 DNPAOs나 DNGAOs에 의한 탈질화로 판단되었다. 또한, 인 방 출은 1차 회분식 실험결과와 유사하게 나타났으나, $\mathrm{NO}_{3}{ }^{-}$가 투입되는 비포기 단계에서 R1과 R2에서도 인의 흡수가 원활하게 발생하지는 못하였다.

위의 결과들을 종합해 볼 때 R1의 경우 인의 제거 에 있어 PAOs와 DNPAOs 중 PAOs의 역할이 크다는 것을 알 수 있다. 왜냐하면 Fig. 13(b)에서 $\mathrm{NO}_{3}{ }^{-}$가 투 입된 경우 인의 제거가 감소하였기 때문이다. 만약 DNPAOs의 활동이 활발하였다면 $\mathrm{NO}_{3}{ }^{-}$의 제거와 함 께 인의 제거도 활발하게 발생하였을 것이다. 또한 질 소의 제거에 있어서도 DNPAOs보다는 DNGAOs의 기여도가 큰 것으로 판단된다. 왜냐하면 $\mathrm{NO}_{3}{ }^{-}$가 투입 됨에 따라 $\mathrm{NO}_{3}{ }^{-}$의 제거는 원활하게 발생하나 인의 제 거는 그다지 활발하지 못하였기 때문이다.

$\mathrm{NO}_{3}{ }^{-}$의 투입에 따른 인 제거가 비슷하게 저조한 것 으로 보아 각 반응기에 존재하는 DNPAOs의 역할은 유사하게 낮은 것으로 판단된다. 그리고 $\mathrm{NO}_{3}{ }^{-}$의 감소 량이나 감소속도도 유사한 것으로 보아 DNGAOs의 활동도도 각 반응기별로 큰 차이는 없을 것으로 판단 된다. 다만 연속실험에서 포기 시간에 따른 질소 제거 형태의 차이는 DNGAOs의 활동도 차이로 보기 보다 는 포기 시간의 차이에 따른 독립 영양균인 질산화 미 생물의 활동도 차이에 기인하는 것으로 판단되었다.

\section{4. 결 론}

본 연구에서는 SBR 내에서 포기 시간 변동에 따른 영양염류 제거특성을 연속실험과 회분식 실험을 통하 여 비교 관찰하였다.
1) 용존산소 농도가 $2 \mathrm{mg} / \mathrm{L}$ 이상의 포기 기간 중에도 탈질화가 발생함으로써 DNPAOs와 DNGAOs에 의한 탈질화를 고려할 수 있었다.

2) 초기 포기 시간 3 시간 30 분에서 포기 시간을 1 시간, 2 시간 30 분, 4 시간, 5 시간 30 분으로 변화시켰을 대, 포기 시간 변화에 따른 TOC 농도의 변화는 크게 나타나지 않음으로써 본 실험범위에서는 포기 시 간은 유기물 제거에 큰 영향을 미치지 않았다.

3 ) 포기 시간이 1 시간으로 매우 적은 R1에서는 매우 저조한 $\mathrm{NH}_{4}{ }^{+}-\mathrm{N}$ 제거효율을 나타내었으나, 포기 시 간을 4 시간과 5 시간 30 분으로 길게 유지한 R3와 $\mathrm{R} 4$ 에서는 $95 \%$ 이상의 $\mathrm{NH}_{4}{ }^{+}-\mathrm{N}$ 제거효율을 나타내 었다.

4) 총 질소 제거에 있어서는 포기 2 시간 30 분으로 유 지한 R2에서 가장 높은 제거효율을 나타내었다.

5) 포기 시간을 감소시킬수록 높은 인 방출량과 인 흡 수량을 나타냄으로써 인 제거에 있어서는 포기 시 간을 감소시키는 것이 유리한 것으로 나타났다. 4 시간 이상의 과도한 포기는 인 제거 기작을 파괴함 으로써 전체적인 인 제거효율은 감소하였다.

6) 본 실험에서 인의 제거에 가장 많은 기여를 하는 미 생물은 PAOs이고, 질소 제거에 있어서는 DNPAOs 보다는 DNGAOs의 기여도가 큰 것으로 나타났다.

\section{참 고 문 헌}

김동석, 박영식, 2010, SBR과 SBBR에서 유입 인 농도 감소에 따른 인과 질소의 제거 특성 변화, 한국환경 과학회지, 19(4), 483-490.

김홍태, 김경호, 2007 , 무산소조 $\mathrm{NO}_{3}^{-}-\mathrm{N}$ 농도 변화에 따 른 DNPAOs에 의한 인 제거, 한국환경과학회지, 16(11), 1271-1277.

박영식, 김동석, 2007, $(\mathrm{AO})_{2} \mathrm{SBBR}$ 에서 운전주기에 따 른 질소와 인 제거 특성 비교, 한국환경과학회지, 16(1), 45-53.

박영식, 정노성, 김동석, $2007, \mathrm{~A}_{2} \mathrm{O}$ SBBR에서 비포기 시간 배분에 따른 질소-인 제거 특성 비교, 한국환경 과학회지, 16(7), 311-319.

Artan, N., Tasli, R., Ozgur, N., Orhon, D., 1998, The Fate of phosphate under anoxic conditions in biological nutrient removal activated sludge systems, Biotechnology Letters, 20(11), 1085-1090. 
Bernat, C., Wojnowska-Baryla, I., 2007, Carbon source in aerobic denitrification, Biochem. Eng. J., 36, 116-122.

Brdjanovic, D., Slamet, A., van Loosdrecht, M. C. M., Hooijmans, C. M., Alaerts, G. J., Heijnen, J. J., 1998, Impact of excess aeration on biological phosphorus removal from wastewater, Wat. Res., 32, 200-208.

Carvalho, G., Lemos, P. C., Oehmen, A., Reis, A. A. M., 2007, Denitrifying Phosphoris removal : Linking the process performance with the microbial community structure, Wat. Res., 41, 4383-4396.

Chuang, S. H., Ouyang, C. F., Wang, Y. B., 1996, Kinetic competition between phosphorus release and denitrification on sludge under anoxic condition, Wat. Res., 30(12), 2961-2968.

Dawson, R. N., Murphy, K. L., 1972, The temperature dependency of biological denitrification, Wat. Res., 6, 71-83.

Eaton, A. D., Clesceri, L. S., Greenberg, A. E., 1995, Standard Methods for the Examination of Water and Wastewater, 19th ed., APHA, NW, Washington.

EPA, 1993, Process design manual of nitrogen control, EPA 625/r-93/010, Cincinnati, Ohio.

Jeon, C. O., Park, J. M., 2000, Enhanced biological phosphorus removal in a sequencing batch reactor supplied with glucose as a sole carbon source, Wat. Res., 34(7), 2160-2170.

Kim, Y. G., Cho, I. H., 2006, A study on the removal of nitrogen and phosphorus of municipal wastewater with biological coated media, Korean Journal of Environmental Health, 32(1), 27-35.

Kishida, N., Tsuneda, S., Sudo, R., 2006, Anaerobic/ oxic/anoxic granular sludge process as an effective nutrient removal process utilizing denitrifying phosphate-accumulating organisms, Wat. Res., 40, 2303-2310.

Oehmen, A., Saunders, A. M., Vives, M. T., Yuan, Z., Keller, J., 2006, Competition between polyphosphate and glycogen accumulating organisms in enhanced biological phosphorus removal systems with acetate and propionate as carbon sources, Journal of Biotechnology, 123, 22-32.

Saito, T., Brdjanovic, D., van Loosdrecht, M. C. M, 2004, Effect of nitrite on phsphate uptake by phosphate accumulating organisms, Wat. Res, 38, 3760-3768.

Shi, H. P., Lee, C. M., 2006, Combining anoxic denitrifying ability with aerobic-anoxic phosphorusremoval examinations to screen denitrifying phosphorus-removing bacteria, International Biodeterioration \& Biodegradation, 57, 121-128. 